\begin{tabular}{|c|c|c|}
\hline $\begin{array}{l}P^{\circ} \\
0 \\
\\
\end{array}$ & $\begin{array}{c}\text { UNIVERSITAS AHMAD DAHLAN } \\
\text { JURNAL BIOEDUKATIKA } \\
\text { http://journal.uad.ac.id/index.php/BIOEDUKATIKA } \\
2338-6630 \text { (Print) }\end{array}$ & \\
\hline
\end{tabular}

\title{
Miskonsepsi ekologi: Sebuah analisis hasil tes kompetisi sains Madrasah Aliyah
}

\author{
Jahidin $^{\text {a, 1*, La Rabani }}{ }^{\text {b, } 2}$

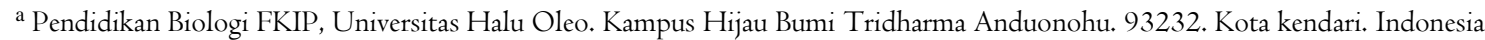 \\ b PGSD FKIP, Universitas Halu Oleo. Kampus Hijau Bumi Tridharma Anduonohu. 93232. Kota kendari. Indonesia \\ 1]jahidin_bio@yahoo.co.id*,2larabani59@gmail.com \\ *korespondensi penulis
}

\begin{tabular}{ll}
\hline Informasi artikel \\
\hline Sejarah artikel: \\
Diterima & 14 September 2017 \\
Revisi & 28 Februari 2018 \\
Dipublikasikan & 13 Maret 2018 \\
\hline
\end{tabular}

Kata kunci:

Kompetisi sains

Madrasah aliyah

Materi ekologi

Miskonsepsi

Siswa

\begin{abstract}
ABSTRAK yang menyimpang dari kaidah-kaidah ilmiah. Kajian ini menjadi rujukan guru biologi Madrasah Aliyah (MA) dalam mereduksi miskonsepsi ekologi sebelum pelaksanaan lomba Kompetisi Sains Madrasah (KSM). Penelitian ini bertujuan mengungkap persentase miskonsepsi materi ekologi dan menyusun deskripsi miskonsepsi pada setiap sub materi ekosistem, bioremediasi, konservasi, pencemaran, populasi, adaptasi, dan simbiosis. Instrumen tes yang digunakan adalah soal KSMMA Kementerian Agama Republik Indonesia tahun 2017. Persentase soal materi ekologi adalah $15 \%$ dari total soal 100 nomor dengan gradasi 3 butir soal adaptasi, 3 butir soal pencemaran, 2 butir soal simbiosis, 3 butir soal ekosistem, dan masingmasing 1 butir soal populasi, komunitas, konservasi, dan bioremediasi. Subyek penelitian adalah peserta lomba KSM-MA Provinsi Sulawesi Tenggara tahun 2017 berjumlah 14 siswa, yaitu peserta dari 12 Kabupaten dan 2 Kota Madya. Analisis miskonsepsi melibatkan dua tahap kegiatan, yaitu pengidentifikasian dan pendeskripsian miskonsepsi. Hasil penelitian menunjukkan miskonsepsi materi ekologi mencapai 64\%. Miskonsepsi terjadi pada semua sub materi dengan persentase yang berbeda, yaitu konservasi, bioremediasi, pupulasi, pencemaran, ekosistem, adaptasi, komunitas, dan simbiosis. Persentase miskonsepsi tertinggi terjadi pada sub materi konservasi, sedangkan terendah terjadi pada sub materi simbiosis.
\end{abstract}

Key word:

Science competition

Madrasah aliyah

Ecological material

Misconception

Student

\begin{abstract}
Misconception Ecology: An Analysis Of The Test Results Of Sains Madrasah Aliyah Competition. The misconception of ecological material is a misunderstanding of ecological concepts or sub-concepts that deviate from scientific rules. This study is important because it is the reference of the biology teacher of Madrasah Aliyah (MA) in reducing the ecological misconception before the implementation of the Madrasah Science Competition (KSM). This study aims to reveal the percentage of misconceptions of ecological material and develop a description of misconception on each sub-material ecosystem, bioremediation, conservation, pollution, population, adaptation, and symbiosis. The test instrument used is the KSM-MA of the Ministry of Religious Affairs of the Republic of Indonesia in 2017. The percentage of ecological matter is $15 \%$ out of a total of 100 questions. Gradation item consists of 3 items about adaptation, 3 items about contamination, 3 items about symbiosis, 2 items about ecosystem, and each 1 item about population, community, conservation, and bioremediation. The subjects were 14 participants of KSM-MA contest in Southeast Sulawesi Province in 2017. The contestants came from 12 regencies and 2 municipalities. Misconception analysis involves two stages of activity, the identification and description of misconception. The results showed $64 \%$ misconception of ecological material. Sub-material with a misconception level below $50 \%$ occurs in the symbiotic and the community, while the misconception level above $50 \%$ includes ecosystems, pollution, bioremediation, population, and conservation.
\end{abstract}

Copyright (C) 2018 Universitas Ahmad Dahlan 


\section{Pendahuluan}

Ekologi merupakan salah satu materi bidang lomba Kompetisi Sains Madrasah (KSM) Madrasah Aliyah (MA) Kementerian Agama Republik Indonesia. Materi ekologi memiliki persentase yang cukup tinggi dalam kasus miskonsepsi lebih dari 30\% (Margalita, Rachmadiarti, \& Prastiwi, 2015), namun hasil ini masih terbatas pada dua sekolah dalam proses pembelajaran sedangkan yang dilakukan peneliti dengan menganalisis peserta lomba KSM-MA.

Pelaksanaan KSM-MA bertujuaan untuk menumbuhkan minat terhadap sains, menumbuhkan budaya kompetitif, memotivasi siswa untuk meningkatkan kualitas diri (intelektual, emosional dan spiritual), berkreatifitas dan berprestasi (Direktorat Jenderal Pendidikan Islam, 2017). Melalui KSM biologi, siswa madrasah diharapkan terlatih dan terbiasa meningkatkan daya nalar, kreartivitas, dan berpikir kritis.

Siswa perlu mempersiapkan diri dengan memiliki pemahaman yang tuntas untuk sukses dalam lomba KSM-MA biologi diantaranya pada materi ekologi. Walaupun dasar-dasar pengetahuan ekologi telah dipelajari pada jenjang Madrasah Ibtidaiyah (MI) dan Madrasah Tsanawiyah (MTs), miskonsepsi diduga masih terjadi. Sebab, memahami materi ekologi membutuhkan berpikir tingkat tinggi. Karena itu, materi ekologi dalam ilmu biologi diposisikan setelah materi keanekaragaman hayati, anatomi, dan fisiologi, serta sebelum materi evolusi. Berdasarkan pertimbangan hirarki ini, pemahaman materi ekologi memerlukan pelibatan daya nalar, kreativitas, dan berpikir kritis.

Dasar-dasar materi ekologi yang dipelajari pada jenjang MI meliputi materi upaya pelestarian makhluk hidup, hubungan antar komponen ekosistem dan penyesuaian diri makhluk hidup. Sedangkan pada jenjang MTs adalah interaksi makhluk hidup dan lingkungannya, pencemaran lingkungan, perubahan iklim dan dampaknya bagi ekosistem, serta teknologi ramah lingkungan. Seluruh dasar pengetahuan ini seharusnya menjadi penguat pemahaman konsep ekologi sehingga kesalahpahaman konsep (miskonsepsi) materi ekologi sewajarnya tidak terjadi. Hasil-hasil penelitian telah membuktikan pemahaman materi baru tergantung pada pengetahuan awal prior knowledge. Purwati (2016) melaporkan pengetahuan awal berkontribusi $43,3 \%$ terhadap pemahaman konsep. Dengan demikian, peserta lomba KSM yang memiliki fondasi pengetahuan ekologi yang baik akan sukses dalam lomba KSM. Akan tetapi, pemberdayaan pengetahuan awal ini dalam pembelajaran biologi khususnya materi ekologi masih minim dan belum membudaya.
Miskonsepsi materi ekologi sering terjadi pada siswa (Cetin, Ertepinar, \& Geban, 2015; Karl, Toonen, Grant, \& Bowen, 2012; Murat, Kanadli, \& Ünişen, 2011; Yücel \& Özkan, 2015), namun kesalahpahaman seakan tidak pernah terhenti. Pernyataan yang berkembang menyatakan miskonsepsi terjadi karena guru mengajar sesuai dengan tuntutan kurikulum reguler. Hal ini memberi kesan peran guru biologi yang belum maksimal mentransfer pengetahuan dan keterampilan sebagai sebuah pengetahuan baru atau pengalaman nyata bagi siswa. Kaur (2013) menyatakan para siswa masuk kelas bersama gagasan yang tidak tepat, tidak sesuai dengan penjelasan ilmiah, dan memiliki kesalahpahaman.

Penelitian telah memberikan banyak bukti bahwa siswa belajar materi ekologi dengan gagasan yang mereka ciptakan ketika memahami dunia nyata mereka. Siswa mempertahankan konsepsi ekologi berdasarkan pengalaman yang cenderung membentuk beragam gagasan yang tidak ilmiah. Jika peserta lomba KSM cenderung menyimpan gagasan ekologi yang tidak ilmiah, potensi mengalami kegagalan dalam lomba KSM cukup besar. Sebaliknya, peserta lomba KSM yang menyimpan gagasan-gagasan ekologi berdasarkan kaidah-kaidah ilmiah cenderung sukses menghadapi lomba KSM. Oleh karena itu, peserta lomba KSM yang siap berkompetisi adalah mereka yang tidak menyimpan gagasan ekologi yang berpotensi miskonsepsi.

Kajian miskonsepsi materi ekologi dalam tulisan ini memberikan informasi kesalahpahaman sub materi ekosistem, bioremediasi, konservasi, komunitas, pencemaran, populasi, adaptasi, dan simbiosis. Analisis miskonsepsi dalam penelitian ini tanpa mempertimbangkan adanya sumber-sumber penyebabnya, seperti yang diakibatkan oleh praduga, pemahaman nonsantifik siswa, kesalahpahaman konseptual, kesalahpahaman vernakuler, dan kesalahpahaman faktual. Walaupun analisis ini merupakan yang kesekian, namun berbeda dengan laporan miskonsepsi ekologi yang sudah ada (Beals, Krall, \& Wymer, 2012; Murat et al., 2011; Yücel \& Özkan, 2015) serta penting untuk diungkap.

\section{Metode}

Sampel penelitian adalah peserta lomba KSM berjumlah 14 siswa MA. Setiap siswa peserta lomba merupakan wakil dari 14 Kota/Kabupaten di Provinsi Sulawesi Tenggara yang telah ditetapkan sebagai pemenang atau terbaik berdasarkan hasil seleksi yang diselenggarakan panitia lomba tingkat Kota/Kabupaten. 
Instrumen tes KSM materi ekologi MA tingkat Provinsi Sulawesi Tenggara adalah tes pilihan ganda berjumlah 15 soal. Tes KSM dikembangkan oleh Kementerian Agama Republik Indonesia. Kemasan tes materi ekologi meliputi materi ekosistem, bioremediasi, konservasi, komunitas, pencemaran, populasi, adaptasi, dan simbiosis. Persentase distribusi soal ekologi $15 \%$ dari total soal 100 nomor. Gradasi soal tidak merata, yaitu 3 soal adaptasi, 3 soal pencemaran, 2 soal simbiosis, 3 soal ekosistem, dan masing-masing 1 soal populasi, komunitas, konservasi, dan bioremediasi.

Teknis analisis miskonsepsi menggunakan dua tahapan kegiatan, yaitu tahap investigasi miskonsepsi dan tahap pendeskripsian miskonsepsi. Tahap investigasi adalah proses pengidentifikasian miskonsepsi yang ditempuh dengan cara memeriksa hasil pekerjaan peserta lomba KSM dengan menganalisis jawaban yang salah atau kurang tepat. Penetapan miskonsepsi dengan mempertimbangkan pilihan jawaban selain pilihan jawaban benar, menganalisis pilihan jawaban salah dan mengkonfirmasikannya dengan terminologi menurut para ahli (expert) menggunakan Encyclopedia of Biology (Rittner \& McCabe, 2004) dan Life on Earth: An Encyclopedia of Biodiversity, Ecology and Evolution (Eldredge, 2002). Usai penetapan miskonsepsi dilanjutkan dengan tahap pendeskripsian, yaitu penyusunan narasi miskonsepsi yang menggambarkan adanya kesalahpahaman yang menyimpang dari konsep yang sebenarnya. Deskripsi miskonsepsi dikembangkan pada setiap sub materi ekologi (ekosistem, bioremediasi, konservasi, pencemaran, populasi, adaptasi, dan simbiosis) secara jelas dan terperinci sehingga memudahkan pengenalan kesalahpahaman.

\section{Hasil dan pembahasan}

Miskonsepsi materi ekologi yang diamati terdiri dari delapan sub materi yaitu ekosistem, bioremediasi, konsevasi, komunitas, pencemaran, populasi, adaptasi dan simbiosis. Temuan hasil analisis miskonsepsi materi ekologi pada kompetisi sains madrasah cukup tinggi sebagaimana yang tersaji pada gambar 1 .

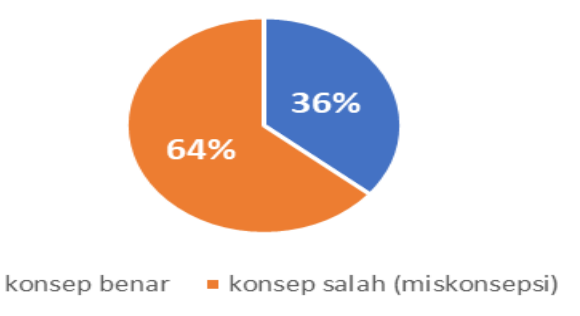

gambar I. Persentase konsep dan miskonsepsi materi ekologi
Hasil analisis yang tersaji pada gambar 1 membuktikan dengan kuat miskonsepsi materi ekologi mencapai 64\%. Besarnya persentase miskonsepsi materi ekologi pada kompetisi sains madrasah perlu mendapatkan perhatian khusus oleh berbagai pihak terutama guru, mengingat miskonsepsi terjadi pada sebuah kompetisi sains yang diselenggarakan di tingkat provinsi. Persentase miskonsepsi pada masing-masing sub materi tersaji pada gambar 2.

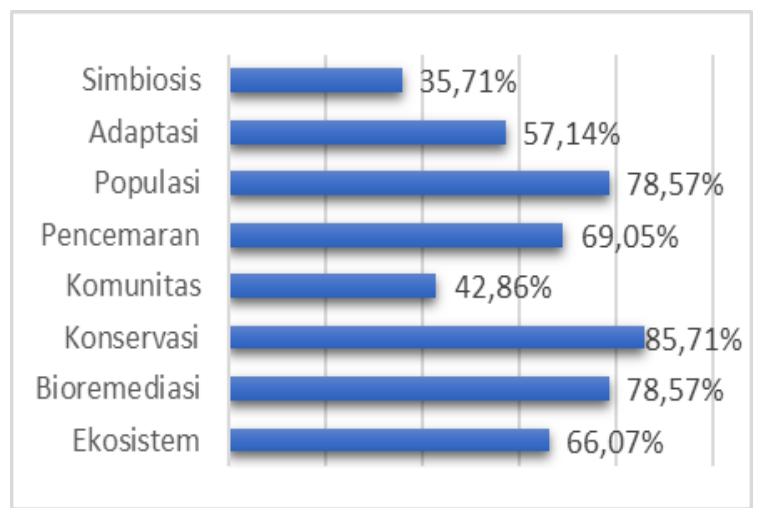

gambar 2. Persentase miskonsepsi per sub materi ekologi

Berdasarkan sebaran yang tersaji pada gambar 2 kisaran persentase miskonsepsi per sub materi 35,71 - $85,71 \%$ dengan persentase miskonsepsi tertinggi terjadi pada materi konservasi, sedangkan sub materi simbiosis adalah yang paling rendah miskonsepsinya. Dua sub materi dengan miskonsepsi di bawah level 50\% terdapat pada materi simbiosis dan komunitas. Sub materi adaptasi, ekosistem, pencemaran, bioremediasi, populasi, dan konservasi menempati kisaran miskonsepsi di atas50 \%.

Timbulnya miskonsepsi ekologi dalam kognisi siswa dapat dipengaruhi oleh banyak faktor, seperti kesalahpahaman materi yang diperoleh pada jenjang pendidikan sebelumnya atau karena ketidaktuntasan memahami konsep/sub konsep ekologi. Jika sebuah konsep/sub konsep ekologi terindikasi miskonsepsi, maka miskonsepsi semakin meluas seiring dengan berkembangnya keterhubungan konsep/sub konsep tersebut. Menurut National Research Council (1997), miskonsepsi terjadi disebabkan pemahaman nonsaintifik dan kesalahpahaman konseptual. Pemahaman nonsaintifik adalah pemahaman yang diperoleh dari sumber selain pendidikan ilmiah, sedangkan kesalahpahaman konseptual adalah pemahaman yang muncul ketika siswa diajarkan informasi ilmiah dengan cara yang tidak menggiring mereka menghadapi paradoks yang dihasilkan dari praduga mereka sendiri dengan pemahaman nonsaintifik sehingga siswa membangun model salah hingga menyebabkan ketidaknyamanan dalam memahami konsep. 
Deskripsi miskonsepsi materi ekologi berdasarkan hasil analisis yang bersumber dari delapan sub materi disajikan pada Tabel 1.

Tabel I. Deskripsi miskonsepsi materi ekologi pada kompetisi sains madrasah

\begin{tabular}{|c|c|}
\hline No & Deskripsi miskonsepsi materi ekologi \\
\hline 1 & $\begin{array}{l}\text { Protozoa yang hidup dalam pencernaan rayap dan } \\
\text { tanaman anggrek yang menempel pada pohon } \\
\text { mangga adalah contoh simbiosis parasitisme. }\end{array}$ \\
\hline 2 & $\begin{array}{l}\text { Jika kondisi lingkungan tidak menguntungkan, } \\
\text { Mucor sp. membentuk struktur sporangispor dan } \\
\text { hifa. }\end{array}$ \\
\hline 3 & $\begin{array}{l}\text { Kepadatan populasi adalah jumlah seluruh } \\
\text { individu penyusun populasi. }\end{array}$ \\
\hline 4 & $\begin{array}{l}\text { Logam } \mathrm{Al} \text { (aluminium) dan } \mathrm{Ag} \text { (perak) lebih } \\
\text { beracun dan berbahaya dibandingkan } \mathrm{Hg} \\
\text { (mercuri). }\end{array}$ \\
\hline 5 & $\begin{array}{l}\text { Angin, nutrien, air, intensitas cahaya, dan iklim } \\
\text { dikelompokkan sebagai faktor biotik yang } \\
\text { mempengaruhi struktur dan organisasi komunitas. }\end{array}$ \\
\hline 6 & $\begin{array}{l}\text { Tumbuhan gurun beradaptasi dengan cara } \\
\text { mempunyai batang berongga. }\end{array}$ \\
\hline 7 & $\begin{array}{l}\text { Tingkatan trofik II dalam jaring-jaring makanan } \\
\text { adalah hewan pemakan hewan lain. }\end{array}$ \\
\hline 8 & $\begin{array}{l}\text { Konservasi hewan secara in situ adalah taman } \\
\text { safari dan kebun raya. }\end{array}$ \\
\hline 9 & $\begin{array}{l}\text { Kadar } \mathrm{Hb} \text { manusia akan menurun jika hidup di } \\
\text { dataran tinggi. }\end{array}$ \\
\hline 10 & $\begin{array}{l}\text { Suatu aliran sungai dapat terbebas dari polutan } \\
\text { bila ada organisme fotosintesis dan terjadi } \\
\text { evaporasi. }\end{array}$ \\
\hline 11 & $\begin{array}{l}\text { Komponen biotik minimal yang harus dimiliki } \\
\text { ekosistem agar dapat mendaur ulang nutrien } \\
\text { adalah produsen dan konsumen. }\end{array}$ \\
\hline 12 & $\begin{array}{l}\text { Kadar polutan dalam jaringan tubuh hewan } \\
\text { akuatik yang tercemar Timbal }(\mathrm{Pb}) \text { makin banyak } \\
\text { seiring dengan waktu melalui proses } \\
\text { biomagnifikasi. }\end{array}$ \\
\hline
\end{tabular}

Urutan deskripsi miskonsepsi tidak menggambarkan tingkatan persentase miskonsepsi tertinggi sampai dengan terendah, atau sebaliknya. Deskripsi sub materi yang tertinggi miskonsepsinya adalah konservasi, yakni siswa meyakini contoh konservasi hewan secara in situ adalah taman safari dan kebun raya. Sub materi yang paling rendah miskonsepsinya adalah simbiosis, yaitu siswa meyakini bahwa contoh simbiosis parasitisme adalah protozoa dalam pencernaan rayap dan tanaman anggrek yang menempel pada pohon mangga. Temuan ini menjadi bukti ketidaktuntasan pemahaman antar sub materi ekologi beragam. Minkonsepsi-miskonsepsi ini dapat bertahan atau berubah menjadi konsep yang benar. Upaya menangani miskonsepsi menjadi konsep yang benar sangatlah sulit, butuh waktu dan proses. Walaupun demikian, miskonsepsi dapat diperbaiki melalui penerapan model pembelajaran (Indriani, 2016). Rekomendasi Indriani ini masih perlu dikaji kembali, khususnya keterkaitannya dengan kurikulum yang berlaku saat ini. Pembelajaran biologi difasilitasi dengan empat model pembelajaran, yaitu inquiry, discovery, PBL, PjBL yang diterapkan melalui metode saintifik.

Peserta lomba KSM dengan kesiapan yang matang dalam berkompetisi adalah mereka yang minim atau tanpa miskonsepsi. Berdasarkan fakta yang menunjukkan adanya miskonsepsi materi ekologi, perbaikan miskonsepsi ekologi saat ini bersifat penting dan mendesak. Perbaikan dapat dilakukan dengan mempertimbangkan pengetahuan awal siswa, pengalaman sehari-hari mereka, dan menghubungkannya dengan konteks ekologi yang mudah dimengerti siswa. Seiring dengan pengulangan dan aplikasinya, hubungan ini sangat penting bagi siswa dalam meretensi materi ekologi. Realisasi ini ditempuh melalui pembelajaran materi ekologi yang tidak sekedar mengenalkan sederetan konsep, fakta, atau prosedur, tetapi menyeimbangkan antara kognitif, psikomotorik, dan afektif.

Berdasarkan kurikulum yang berlaku pada MA, baik KTSP maupun kurikulum 2013 revisi, serta memperhatikan keterkaitannya dengan kurikulum KSM, materi ekologi dipelajari pada topik ekosistem dan perubahan lingkungan. Kedua materi ini bertalian erat dengan bahasan sub materi ekologi yang telah dipelajari pada jenjang MI dan MTs. Oleh sebab itu, miskonsepsi ekologi sewajarnya tidak terjadi karena pengetahuan konseptual ekologi didukung oleh pengetahuan awal (prior knowledge) di MI meliputi materi upaya pelestarian makhluk hidup, hubungan antar komponen ekosistem dan penyesuaian diri makhluk hidup. Pada jenjang MTs, pengetahuan awal yang mendasari pemahaman ekologi adalah interaksi makhluk hidup dan lingkungannya, pencemaran lingkungan, perubahan iklim dan dampaknya bagi ekosistem, dan teknologi ramah lingkungan. Temuan ini menjadi bukti bahwa miskonsepsi materi ekologi yang terungkap melalui lomba KSM disebabkan oleh fondasi pengetahuan yang lemah. Dasar pengetahuan yang lemah mempengaruhi proses kognitif siswa dalam mengaitkan konsep-konsep yang saling berhubungan antara materi ekologi dengan beberapa konsep biologi lainnya sehingga menjadi penyumbang terjadinya pemahaman materi ekologi yang tidak tuntas.

Tingkatan miskonsepsi secara berturut-turut dari tertinggi ke yang terendah adalah konservasi, populasi, bioremediasi, pencemaran, ekosistem, adaptasi, komunitas, dan simbiosis. Tujuh dari delapan sub materi ekologi dipelajari di MI dan 
MTs. Sewajarnya, tujuh sub materi selain bioremediasi tidak terjadi miskonsepsi atau miskonsepsinya lebih rendah dibandingkan bioremediasi. Berdasarkan kurikulum MA, bioremediasi tidak diajarkan dalam topik spesifik, tetapi menjadi bagian materi ekosistem dan perubahan lingkungan. Kedua materi ini diajarkan dalam kompetensi dasar yang berbeda di kelas X, dimulai dengan ekosistem dan dilanjutkan dengan perubahan lingkungan. Berdasarkan hal tersebut maka terjadinya miskonsepsi pada sub materi bioremediasi memang dimungkinkan terjadi, namun miskonsepsi pada tujuh indikator lainnya seharusnya tidak perlu terjadi karena dasar pengetahuannya telah dipelajari. Tidak mantapnya pengetahuan awal materi ekologi telah terbukti menjadi pemicu utama terjadinya miskonsepsi. Sebenarnya, tingkatan pengetahuan seluruh materi ekologi terdiri dari pengetahuan faktual, konseptual, dan prosedural. Tiga pengetahuan ini terindikasi sangat lemah diajarkan pada jenjang pendidikan MI dan MTs, atau daya ingat (retensi) siswa yang sangat lemah. Kurang efektifnya proses aktivasi pengetahuan awal dalam belajar materi ekologi di MA menjadi pemicu positif miskonsepsi. Ditegaskan Dixon (2000), mempelajari materi baru, siswa harus memiliki pengetahuan awal terkait materi baru sehingga memungkinkan menyerap pengetahuan baru. Hasil penelitian menunjukkan besaran sumbangan (effect size) pengetahuan awal terhadap penyelesaian ujian formatif sebesar 60\% (Magno, 2016).

Temuan miskonsepsi dalam penelitian ini memperkaya informasi miskonsepi materi ekologi yang telah dilaporkan sebelumnya. Seperti, miskonsepsi pada topik ekosistem, polusi lingkungan, pemanasan global, lingkungan, habitat, rantai makanan, siklus materi, efek rumah kaca, hujan asam, dan populasi (Yücel \& Özkan, 2015). Hasil penelitian ini telah menunjukkan dengan kuat bahwa miskonsepsi ekologi terus terjadi dan sulit dihindari. Hasil penelitian ini juga sejalan dengan beberapa laporan yang menyimpulkan materi ekologi sering ditemukan miskonsepsi (Andrews et al., 2017; Deshmukh \& Deshmukh, 2007; Köse, 2008; Nehm \& Reilly, 2007; Yücel \& Özkan, 2015).

Penyebab terjadinya miskonsepsi ekologi dimungkinkan oleh adanya konsepsi ekologi yang bersumber dari pengalaman atau sumber-sumber bacaan non saintifik. Selain itu, kurangnya pengalaman, lemahnya kemampuan mengaplikasikan konsep ekologi dalam kehidupan sehari-hari, serta rendahnya proses-proses kognitif level kognitif tingkat tinggi akan menjadi pemicu munculnya gangguan belajar materi ekologi, seperti pemahaman yang tidak lengkap mengenai pengetahuan faktual, konseptual, dan prosedural. Hal ini dibuktikan dengan kisaran miskonsepsi sub-sub materi ekologi 35,71 - 85,71\%. Sebagai contoh, sub materi konservasi merupakan paling tinggi miskonsepsinya dengan pamahaman yang salah yakni siswa meyakini bahwa contoh konservasi hewan secara in situ adalah taman safari dan kebun raya. Walaupun sub materi simbiosis telah dipelajari siswa sejak MI dan MTs, temuan penelitian ini siswa masih meyakini bahwa protozoa yang hidup dalam pencernaan rayap dan tanaman anggrek yang menempel pada pohon mangga adalah contoh simbiosis parasitisme. Kedua contoh kasus ini adalah miskonsepsi pengetahuan faktual.

Keberadaan miskonsepsi materi ekologi dalam kognitif siswa tidak mudah berubah menjadi konsep yang benar. Walaupun demikian, miskonsepsi ini dapat diarahkan menjadi konsep benar. National Research Council (1997) merekomendasikan perbaikan miskonsepsi melalui pengidentifikasian kesalahpahaman siswa, pemberian wadah kepada siswa mengenal kesalahpahaman mereka, dan membantu siswa merekonstruksi dan menginternalisasi pengetahuan mereka. Cara perbaikan miskonsepsi ini menantang siswa merekonstruksi kesalahpahaman. Menurut Kaur (2013) seharusnya siswa datang ke sekolah mereka untuk menjadi tahu karena telah memiliki ide-ide bagaimana alam bekerja, serta mereka memiliki harapan berdasarkan pengalaman masa lalu yang mungkin mereka dapat aplikasikan. Menurut Gall, Gall, Jacobsen, \& Bullock (1990) belajar bagaimana belajar tidak diserahkan sepenuhnya kepada siswa, tetapi harus diajarkan atau dilatihkan. Jika cara-cara ini dilakukan guru-guru biologi dalam mengajarkan materi ekologi, dipastikan siswa sedikit atau bahkan tidak memiliki miskonsepsi.

Temuan penelitian ini selain memberikan sumbangsih perbaikan pembelajaran materi ekologi pada tingkat MTs maupun MA, juga menjadi rujukan persiapan pelaksanaan KSM tingkat provinsi. Jika merujuk pada tingginya persentase miskonsepsi materi ekologi, seleksi KSM tingkat sekolah maupun tingkat kota/kabupaten sebaiknya dilaksanakan dengan ketat. Kualitas seleksi KSM pada dua tingkatan ini menjadi filter terbaik untuk meloloskan peserta KSM yang siap berkompetisi di level provinsi. Siswa yang matang pengetahuannya dipastikan tampil menjadi peserta KSM terbaik, yaitu siswa yang tidak menunjukkan adanya miskonsepsi materi ekologi. Jika memiliki miskonsepsi, miskonsepsinya berada pada level minimal.

Selain pelaksanaan seleksi KSM yang diperketat, alternatif lainnya dalam meminimalisir 
terjadinya miskonsepsi ekologi adalah diselenggarakannya proses pembinaan siswa peserta lomba maupun guru pelatih KSM. Pembinaan siswa bertujuan mematangkan pengetahuan ekologi, baik pengetahuan faktual, konseptual, maupun prosedural. Sedangkan pembinaan terhadap guru pelatih KSM dimaksudkan memperkuat kompetensi pedagogik maupun kompetensi profesional. Kompetensi pedagogik melahirkan inovasi-inovasi pembelajaran materi ekologi yang memudahkan siswa mengembangkan keterampilan berpikir, misalnya berpikir kritis, kreatif, dan berpikir tingkat tinggi. Berbeda dengan kompetensi pedagogik, kompetensi profesional mengarah pada penguasaan materi ekologi.

Guru yang menguasai materi ekologi (termasuk keluwesan maupun kedalamannya), mudah baginya menyelenggarakan pembelajaran yang mengakomodir terjadinya tantangan-tantangan belajar berorientasi pemberdayaan berpikir, akan tetapi jika penguasaan materi lemah, sulit bagi guru membelajarkan materi ekologi. Kedua kompetensi ini penting dilatihkan pada guru pelatih atau pembina KSM. Hasil penelitian menunjukkan 184 guru biologi SMA dan SMK mengalami peningkatan kompetensi paedagogik dan meningkatkan kemampuan berpikir kritis guru pelatih OSN (Olimpiade Sains Nasional) IPA tingkat SD dan SMP, namun tidak berpengaruh signifikan terhadap keterampilan berpikir kreatif (Jahidin, 2015a, 2015b).

\section{Simpulan}

Miskonsepsi materi ekologi peserta KSM Provinsi Sulawesi Tenggara mencapai 64\%. Miskonsepsi terjadi pada semua sub materi dengan persentase miskonsepsi yang berbeda, yaitu konservasi, bioremediasi, populasi, pencemaran, ekosistem, adaptasi, komunitas, dan simbiosis. Persentase miskonsepsi tertinggi terjadi pada sub materi konservasi, sedangkan terendah terjadi pada sub materi simbiosis. Upaya menangani miskonsepsi ekologi perlu dilakukan diantaranya dengan meningkatkan kemampuan guru, serta diperlukan penguatan pembentukan pengetahuan awal siswa di tingkat MI dan MTs karena sebagian besar materi ekologi pada tingkat SMA berdasar pada materi saat MI dan MTs.

\section{Ucapan terima kasih}

Penulis menyampaikan ucapan terima kasih kepada Kepala Kantor Wilayah Kementerian Agama (Kanwil Kemenag) Provinsi Sulawesi Tenggara yang telah memberikan kepercayaan pada penulis sebagai dewan juri KSM biologi Madrasah Aliyah tingkat Provinsi Sulawesi Tenggara (Sultra) Tahun 2017.

\section{Referensi}

Andrews, T. M., Price, R. M., Mead, L. S., McElhinny, T. L., Thanukos, A., Perez, K. E., ... Lemons, P. P. (2017). Biology Undergraduates' Misconceptions about Genetic Drift. CBELife Sciences Education, 11(3), 248-259. https://doi.org/10.1187/cbe.11-12-0107

Beals, A. M., Krall, R. M., \& Wymer, C. L. (2012). Energy Flow through an Ecosystem: Conceptions of In-service Elementary and Middle School Teachers. International Journal of Biology Education, 2(1). Diambil dari www.ijobed.com

Cetin, G., Ertepinar, H., \& Geban, O. (2015). Effects of conceptual change text based instruction on ecology, attitudes toward biology and environment. Educational Research and Reviews, 10(3), 259-273. https://doi.org/10.5897/ERR2014.2038

Deshmukh, N. D., \& Deshmukh, V. M. (2007). A study of students' misconceptions in biology at the secondary school level. In International conference to review research in Science, Technology and Mathematics Education. Mumbai, India: Homi Bhabha Centre for Science Education, TIFR. Diambil dari http://www.hbcse.tifr.res.in/episteme/episteme-2/eproceedings/deshmukh

Direktorat Jenderal Pendidikan Islam. (2017). Petunjuk teknis Kompetisi Sains madrasah 2017. Jakarta.

Dixon, N. M., \& M., N. (2000). Common knowledge: how companies thrive by sharing what they know. Harvard Business School Press. Diambil dari

https://dl.acm.org/ citation.cfm?id= 518642

Eldredge, N. (2002). Life on earth: an encyclopedia of biodiversity, ecology, and evolution. ABCCLIO.

Gall, M. D., Gall, J. P., Jacobsen, D. R., \& Bullock, T. (1990). Tools for Learning: A Guide to Teaaing Study Skills. Alexandria, Virginia: Association for Supervision and Curriculum Development. Diambil dari https://files.eric.ed.gov/fulltext/ED320126.pdf

Indriani, D. E. (2016). Perangkat Pembelajaran Model Cooperative Scripts Untuk Meningkatkan Pemahaman Konsep dan Mengeliminasi Miskonsepsi IPA pada Siswa Sekolah Dasar. JURNAL BIOEDUKATIKA, 4(2), 30. https://doi.org/10.26555/bioedukatika.v4i2.5296

Jahidin, J. (2015a). Dampak pelatihan terhadap kompetensi pedagogik guru biologi Sekolah Menengah Atas. Jurnal Ilmiah BioSmart, 2(2), 20-31. 
Jahidin, J. (2015b). Pengaruh diklat OSN IPA-materi biologi terhadap keterampilan berpikir kritis dan kreatif guru pelatih OSN IPA SD dan SMP. Biodidaktis: Jurnal Pendidikan Biologi, 6(4), 192-199.

Karl, S. A., Toonen, R. J., Grant, W. S., \& Bowen, B. W. (2012). Common misconceptions in molecular ecology: echoes of the modern synthesis. Molecular Ecology, 21(17), 4171-4189. https://doi.org/10.1111/j.1365-294X.2012.05576.x

Kaur, G. (2013). A review of selected literature on causative agents and identification strategies of students' misconceptions. Journal of Educationia Confab, 2(11), 79-94.

Köse, S. (2008). Diagnosing Student Misconceptions: Using Drawings as a Research Method. World Applied Sciences Journal, 32), 283-293. Diambil dari http:// citeseerx.ist.psu.edu/viewdoc/download ?doi=10.1.1.388.382\&rep $=$ rep1\&type $=$ pdf

Magno, C. (2016). The Effect Size of Self-Regulation and Prior Knowledge on Students Performance in an Open High School Program. The International Journal of Research and Review, 11. Diambil dari https://papers.ssrn.com/sol3/papers.cfm?abstr act_id=2892190

Margalita, S., Rachmadiarti, F., \& Prastiwi, M. S. (2015). Analisis miskonsepsi tertinggi materi ekologi pada siswa sekolah menengah atas (SMA). Berkala Ilmiah Pendidikan Biologi (BioEdu), 4(3), 996-1001.
Murat, M., Kanadli, S., \& Ünișen, A. (2011). Seventh Grade Students' Misconceptions about Animals' Reproduction, Growth and Development and Their Likely Resources. Journal of TURKISH SCIENCE EDUCATION, 8(1), 179-197. Diambil dari http://www.tused.org/internet/tused/archive/v8/i1/text/ tusedv8i1a10.pdf

National Research Council, C. on U. S. E. (1997). Science Teaching Reconsidered: a Handbook. Washington: National Academies Press.

Nehm, R. H., \& Reilly, L. (2007). Biology Majors' Knowledge and Misconceptions of Natural Selection. BioScience, 57(3), 263-272. https://doi.org/10.1641/B570311

Purwati, S. (2016). Pengaruh Kemampuan Awal terhadap Pemahaman Konsep Usaha dan Energi. In Prosiding SNFA (Seminar Nasional Fisika dan Aplikasinya) (hal. 100). Surakarta: Universitas Sebelas Maret. https://doi.org/10.20961/prosidingsnfa.v1i0.4522

Rittner, D., \& McCabe, T. L. (2004). Encyclopedia of Biology. New York: Facts On File, Inc.

Yücel, E. Ö., \& Özkan, M. (2015). Determination of secondary school students' cognitive structure, and misconception in ecological concepts through word association test. Educational Research and Review, 10(5), 660-674. https://doi.org/10.5897/ERR2014.2022 